\title{
Channelopathies influence on neurotransmitters monitorable by real time in situ voltammetry, a review and research proposal
}

Francesco Crespi*

Biology Department, GSK, Verona, Italy

\section{Introduction}

Channels are pores and through them ions flow across the cell membrane and depolarize or hyperpolarize the cell. They open in response to voltage changes or binding of a chemical messenger, such as a neurotransmitter (i.e. ligand-gated ion channels). Biochemically, channels are specialized membrane macro-molecular protein complexes divided into distinct protein units called sub-units. Each sub-unit has a specific function and is encoded by a different gene. These proteins play heterogeneous physiological roles such as impulse generation and propagation, synaptic transmission and plasticity, hormonal secretion, hearth rhythm, blood pressure regulation, saltwater balance, cell proliferation and survival. Thus, defects in ion channels function may cause diverse and severe diseases collectively known as channelization [1,2]. They include diabetes, migraine, ataxia, epilepsy, autism, intramuscular, psychiatric, degenerative, renal, lung and cardiovascular diseases. The cause of such diseases may be congenital (mutations in the encoding genes) or acquired (ire. originating from autoimmune attacks) [3-5].

In particular, link between altered activity of the serotonin system and migraine, ataxia, epilepsy and autism have been proposed.

\section{Migraine}

Migraine is a chronic episodic disorder that has been linked to abnormalities in serotonin signaling and abnormal function of a synaptic voltage-gated calcium channel: CACNA1A. More precisely, a low condition of the serotonergic (serotonin, 5-HT) system from the brain-stem raphe nucleus has been implicated in the activation of the trigeminovascular nociceptive pathway [6]. In parallel, it has been reported that the brain-specific P/Q-type Ca2+channel gene CACNA1A acts as a pivotal player in the pathogenesis of migraine [7] and that transgenic expression of human CACNA1A can suppress the lethargic and serotonin-deficient phenotypes of unc- 2 mutant animals, therefore proposing that CACNA1A function might affect the levels of serotonin, a neurotransmitter known to be important in migraine [8] and in particular in Familial hemiplegic migraine (FHM). This is the rare Mendelian dominant form of migraine which is more prevalent in mono-zygotic twins than dizygotic ones. Numerous genetic abnormalities, especially in the genes encoding membrane transport proteins, ion pumps and channels such as CACNA1A, ATP1A2, SCN1A are likely to be involved in this migraine type. Motor weakness and/or paralysis are the symptoms of diagnosis [9].

\section{Ataxia}

Ataxia is a non-specific clinical condition characterized by dysfunction of the areas of the nervous system that control movement, such as the cerebellum [10].

A possible link between cerebellar ataxia and the metabolism of serotonin has been proposed as anti-ataxic effect of buspirone hydrochloride, a serotoninergic 5-hydroxytryptamine1A (5-HT1A) agonist, in a homogenous group of patients characterized by the same well-defined single condition i.e. cerebellary cortical atrophy has been reported [11]. Accordingly, it has been observed that 5-hydroxytryptophan, serotonin precursor, is more effective than placebo improving neurological symptoms in patients with Friedreich ataxia (FA) [12]. FA is an autosomal recessive genetic illness responsible for progressive damage to the nervous system in the spinal cord, in particular of sensory neurons basal for leading muscle motion of the arms and legs via link with the cerebellum [13].

\section{Epilepsy and Autism}

Epilepsy is a crucial medical complication that evolves in subjects with autism [14].

Anomalous cortical development in both autism and forms of epilepsy has been observed. It is known that serotonin plays an essential neurotrophic function during brain development and in both these diseases altered serotonergic functions have been detected [15].

Imaging data and analysis of tissue of epileptic patients, as well as studies in animal models provide evidence that endogenous serotonin (5-HT), the activity of its receptors and pharmaceuticals with serotonin agonist and/or antagonist properties play a significant role in the pathogenesis of epilepsies [16]. On the other hand, a role for altered metabolism of the serotonin precursor, tryptophan, in both epilepsy and autism has been proposed [15].

\section{Psychiatric}

Anxiety disorders, depression, eating disorders are psychiatric diseases in which serotonin is directly involved [17].

Correspondence to: Francesco Crespi, Biology Department, GSK, Verona, Italy, E-mail: fm.crespi@libero.it

Received: January 21, 2018; Accepted: January 25, 2018; Published: January 26 2018 
In particular, the Selective Serotonin Reuptake Inhibitors (SSRIs) have emerged as a major therapeutic advance in psychopharmacology. SSRIs have demonstrated efficacy and tolerability in the treatment of obsessive-compulsive disorder (OCD). They have been found to be effective in the treatment for social anxiety disorder both in reducing total levels of social anxiety and in improving overall clinical condition. Benefits for anorexia nervosa are also observed. SSRIs should also be considered as one of the first-line drugs in the treatment of depression [18].

In addition to the success of pharmacological treatment with SSRIs OCD appeared to be treatable with atypical antipsychotic drugs [19].

Furthermore, the co-existence of serotonergic and dopaminergic dysfunction in the same homogeneous group of drug-naive OCD patients has been monitored [20] therefore proposing complex molecular mechanisms of OCD. This suggests that both the central serotonergic and dopaminergic systems are involved in the pathophysiology of the disorder. Indeed, in randomized, doubleblind, controlled trials evaluating the efficacy of the norepinephrinedopamine reuptake inhibitor (NDRI) bupropion versus SSRIs for treatment of depression in adults it appeared that bupropion and SSRIs have similar effectiveness [21]

Additionally, dopamine is implicated in Parkinson's disease (PD), which is marked by progressive degeneration of midbrain dopaminergic neurons [22,23] and dopamine agonists are being used increasingly as first-line treatment for Parkinson's disease [24].

Various investigations implicate ion channel functions and acetylcholine (Ach) as well as ACh receptors in the development of Alzheimer's disease (AD) $[4,25,26]$.

Finally, functional changes in ion channel activity induced by reactive oxygen species (ROS) and reactive nitrogen species such as nitric oxide (NO) might occur during the aging process [27] and association between rat neutrophil membrane depolarization and NOdependent free radical generation has been shown [28].

\section{Research proposal}

Serotonin, dopamine, Ach, NO are neurotransmitters that can be monitored in vivo in situ and in real time by voltammetry [29-32]. Therefore, it seems possible to propose to couple such electrochemical methodology with the "classic" in vitro methodologies described in the various references cited above for a parallel analysis of the channelopathies that are involving such neurotransmitters. The "classic" in vitro analyses together with voltammetric in vivo, in situ and in real time studies will probably permit a better understanding of their implication in all these diseases and possibly open up new in view for novel therapeutic approaches.

\section{References}

1. Bernard G, Shevell MI (2008) Channelopathies: A review. Pediatr Neurol 38: 73-85. [Crossref]

2. Kim JB (2014) Channelopathies. Korean J Pediatr 57: 1-18. [Crossref]

3. Gargus JJ (2009) Genetic calcium signaling abnormalities in the central nervous system: Seizures, migraine, and autism. Ann N Y Acad Sci 1151: 133-156. [Crossref]

4. Kullmann DM, Waxman SG (2010) Neurological channelopathies: New insights into disease mechanisms and ion channel function. J Physiol 588: 1823-1827. [Crossref]

5. Kleopa KA (2011) Autoimmune channelopathies of the nervous system. Curr Neuropharmacol 9: 458-467. [Crossref]

6. Hamel E (2007) Serotonin and migraine: biology and clinical implications. Cephalalgia 27: 1293-1300. [Crossref]
7. Ophoff RA, van den Maagdenberg AM, Roon KI, Ferrari MD, Frants RR (2001) The impact of pharmacogenetics for migraine. Eur J Pharmacol 413: 1-10. [Crossref]

8. Estevez M (2006) Invertebrate modeling of a migraine channelopathy. Headache 46: S25-S31. [Crossref]

9. Aggarwal M, Puri V, Puri S (2012) Serotonin and CGRP in migraine. Ann Neurosci 19: 88-94. [Crossref]

10. Schmahmann JD (2004) Disorders of the cerebellum: ataxia, dysmetria of thought, and the cerebellar cognitive affective syndrome. J Neuropsychiatry Clin Neurosci 16: 367378. [Crossref]

11. Trouillas P, Xie J, Adeleine P, Michel D, Vighetto A, et al. (1997) Buspirone, a 5-Hydroxytryptamine1A agonist, is active in cerebellar ataxia. Results of a doubleblind drug placebo study in patients with cerebellar cortical atrophy. Arch Neurol 54: 749-752. [Crossref]

12. Trujillo-Martín MM, Serrano-Aguilar P, Monton-Alvarez F, Carrillo-Fumero R (2009) Effectiveness and safety of treatments for degenerative ataxias: A systematic review. Mov Disord 24: 1111-1124. [Crossref]

13. Parkinson MH, Boesch S, Nachbauer W, Mariotti C, Giunti P (2013) Clinical features of Friedreich's ataxia: Classical and atypical phenotypes. J Neurochem 103-117. [Crossref]

14. Bolton PF, Carcani-Rathwell I, Hutton J, Goode S, Howlin P, Rutter M (2011) Epilepsy in autism: Features and correlates. Br J Psychiatry 198: 289-294. [Crossref]

15. Chugani DC (2004) Serotonin in autism and pediatric epilepsies. Ment Retard Dev Disabil Res Rev 10: 112-116. [Crossref]

16. Bagdy G, Kecskemeti V, Riba P, Jakus R (2007) Serotonin and epilepsy. J Neurochem 100: 857-873. [Crossref]

17. Vaswani M, Linda FK, Ramesh S (2003) Role of selective serotonin reuptake inhibitors in psychiatric disorders: A comprehensive review. Prog Neuropsychopharmacol Biol Psychiatry 27: 85-102. [Crossref]

18. Vaswani M, Ramesh S, Kalra H, Sagar R (2005) Use of selective serotonin reuptake inhibitors in neuropsychiatric disorders. In S. P. Shohov (Ed.), Advances in psychology research 33, pp. 161-200). Hauppauge, NY: Nova Science.

19. Hesse S, Müller U, Lincke T, Barthel H, Villmann T, et al. Serotonin and dopamine transporter imaging in patients with obsessive-compulsive disorder. Psychiatry Res 140: 63-72. [Crossref]

20. Perani D, Garibotto V, Gorini A, Moresco RM, Henin M, et al. (2008) In vivo PET study of 5HT2A serotonin and D2 dopamine dysfunction in drug-naive obsessivecompulsive disorder. Neuroimage 42: 306-314. [Crossref]

21. Nieuwstraten CE, Dolovich LR (2001) Bupropion versus selective serotonin-reuptake inhibitors for treatment of depression. Ann Pharmacother 35: 1608-1613. [Crossref]

22. Lin LF, Doherty DH, Lile JD, Bektesh S, Collins F, et al. (1993) GDNF: a glial cell line-derived neurotrophic factor for midbrain dopaminergic neurons. Science 260: 1130-1132. [Crossref]

23. Surmeier DJ, Guzman JN, Sanchez-Padilla J, Schumacker PT (2011) The role of calcium and mitochondrial oxidant stress in the loss of substantia nigra pars compacta dopaminergic neurons in Parkinson's disease. Neuroscience 198: 221-231. [Crossref]

24. Stowe RL, Ives NJ, Clarke C, van Hilten J, Ferreira J, et al. (2007) Dopamine agonist therapy in early Parkinson's disease (Protocol). Cochrane Database Syst Rev 16: CD006564. [Crossref]

25. Isacson O, Seo H, Lin L, Albeck D, Granholm AC (2002) Alzheimer's disease and down's syndrome: roles of APP, trophic factors and ACh. Trends Neurosci 25: 79-84. [Crossref]

26. Schliebs R, Arendt T (2011) The cholinergic system in aging and neuronal degeneration. Behav Brain Res 221: 555-563. [Crossref]

27. Annunziato L, Pannaccione A, Cataldi M, Secondo A, Castaldo P, et al (2002) Modulation of ion channels by reactive oxygen and nitrogen species: a pathophysiological role in brain aging? Neurobiol Aging 23: 819-834. [Crossref]

28. Patel S, Vemula J, Konikkat S, Barthwal MK, Dikshit M (2009) Ion channel modulators mediated alterations in NO-induced free radical generation and neutrophil membrane potential. Free Radic Res 43: 514-521. [Crossref] 
Crespi F (2018) Channelopathies influence on neurotransmitters monitorable by real time in situ voltammetry, a review and research proposal

29. Crespi F (2013a) Serotonin, how to find it...Review Article Xjenza Online - Journal of Malta Chamber of Scientists http://www.mcs.org.mt/ Doi: http://dx.medra.org/10.7423/ XJENZA.2013 .2.02 pp14-22. 2013a.

30. Crespi $\mathrm{F}$ (2013b) Invasive or non-invasive techniques and sensors for real time in vivo sensing in the brain" chapter in the book, laboratory and clinical research: "Microelectrodes: techniques, structures for biosensing and potential applications" Nova Science Publishers.
31. Crespi F (2013c) "In vivo voltammetric evidence that cerebral nitric oxide (NO) is influenced by drugs of abuse: Is NO implicated in their neurotoxicity?" RSC Adv., 2013c, 3, 9803-9808 This journal is @ The Royal Society of Chemistry.

32. Crespi F (2014) Hydrogen peroxide monitored in vivo, in situ and in real time in rat brain, is it a marker of central cholinergic dynamics? Analytical Methods 6: /11741181 DOI: $10.1039 / \mathrm{c} 3 a y 41682 \mathrm{~h}$

Copyright: (C2018 Crespi F. This is an open-access article distributed under the terms of the Creative Commons Attribution License, which permits unrestricted use, distribution, and reproduction in any medium, provided the original author and source are credited. 